\title{
Marine Microorganisms: perspectives for getting involved in cellulosic ethanol
}

\author{
Pablo Intriago $0^{1,2^{*}}$
}

\begin{abstract}
The production of ethanol has been considered as an alternative to replace part of the petroleum derivate. Brazil and the US are the leading producers, but more environmentally friendly alternatives are needed. Lignocellulose has an enormous potential but technology has to be still improve in order to economically produce ethanol. The present paper reviews the potential and problems of this technology and proposes the study of a group of microorganisms with the largest genetic pool, marine microorganism.
\end{abstract}

\section{Introduction}

Countries all over the world are facing a rising demand for fuels, inflation, increase in energy prices, and issues on food and climate control. In 2010, the human population was estimated to be 6.8 billion and projected to reach 7.6 billion in 2020 (U.S. Census Bureau, Statistical Abstract of the United States 2011). At $3.000 \mathrm{Kcal}$ per day, the world average per capita caloric food consumption (World Health Organization, 2003), the world in 2020 would demand the astonishing amount of $22.8 \times 10^{12}$ Kcal per day, comparable to the energy of roughly 16 million barrels of oil equivalent (boe) per day.

The US is the largest petroleum consumer in the World. During 2010, consumed 19.1 million barrels per day, $49 \%$ of this was imported (US Energy Information Administration, 2011). Table 1 shows a comparison on energy consumption between Brazil, the US, China/India as the region most dense populated and the world. Interestingly, though the total vehicles in the US represent almost $24 \%$, the US along consumes $42 \%$ of gasoline consumed in the world. These three country regions with $44 \%$ of the world population used $45 \%$ of the total energy and released $51 \%$ of the $\mathrm{CO}_{2}$ from the consumption of energy in the world (Table 1).

Worldwide, about $27 \%$ of primary energy is used for transportation, thus transportation fuels are promising targets to be replaced for a renewable source as well as for a reduction in greenhouse gas emissions

Correspondence: sffarming@yahoo.com

${ }^{1}$ Empagran, Km 19 1/2 via a la Costa, Guayaquil, Ecuador

${ }^{2}$ South Florida Farming Corp. 3232 Coral Way, Suite 1201, Miami, FL 33145, USA
(Antoni et al. 2007). At the end of the $19^{\text {th }}$ century, Henry Ford, and Nicholas Otto built engines that could run on ethanol. Then which better candidate than ethanol? Table 1 shows the amounts of vehicles in the world has already reached 1 billion units, and the US has by far the largest vehicle per habitant ratio in the world. The last century witnesses the rise, fall and the rebirth of ethanol (Solomon et al. 2007). Unfortunately, different factors played for the demand for alcohol to decrease and left only as an octane enhancer during and after the Great War. Despite health concerns the discovery of tetraethyl lead as antiknocking agent in the beginning of the 20's, almost complete discontinued ethanol use in the car industry till the mid 70's.

As a consequence of OPEC- Arab oil crisis of the 70's, Brazil created in 1975 the National Ethanol Program (PROALCOOL) (Solomon et al. 2007). Under this program, tax and loan incentives were provided by the government to build production facilities. Brazilians incorporated the flexible fuel vehicles, more than any other country in the world, in this way Brazil became an energy independent nation largely to the adoption of legislation requiring ethanol use (Pilgrim, 2009).

In The US, ethanol industry was invigorated in the early 80 's when it became economical to produce ethanol by fermentation. By the 90's MTBE (methyl tertiary- butyl ether), totally replaced lead additives as octane enhancer. Since 2000, the almost uncontrolled growth of supply and demand of ethanol, replacing MTBE (methyl tertiarybutyl ether), also alleviated some of the dependence to oil. In 2005, the renewable fuel standard (RFS) program was created under the Energy Policy Act (EPAct of 2005), and 
Table 1 Population, ethanol, energy consumption and $\mathrm{CO}_{2}$ emissions of Brazil, USA, China/India and in the World

\begin{tabular}{|c|c|c|c|c|}
\hline Unit & Brazil & USA & China/India & World \\
\hline Population (millions, 2010) ${ }^{1}$ & $201.1(2.9 \%)$ & $310.2(4.5 \%)$ & $2,503.2(36.5 \%)$ & 6,853 \\
\hline Total Vehicles (millions, 2010) ${ }^{2}$ & $32.1(3.2 \%)$ & $239.8(23.6 \%)$ & $98.8(9.7 \%)$ & $1,015.3$ \\
\hline Vehicles per habitant & 0.159 & 0.773 & 0.0394 & 0.148 \\
\hline Gasoline consumption, 2008 (thousand Barrels per day) ${ }^{1}$ & $327.1(1.5 \%)$ & 8,989.2 (42.2\%) & $1,693.5(7.9 \%)$ & $21,323.1$ \\
\hline Fuel ethanol production, 2010 (thousand Barrels per day) ${ }^{1}$ & $486.0(32.0 \%)$ & $867.4(57.1 \%)$ & $42.0(2.7 \%)$ & 1520 \\
\hline Fuel ethanol consumption, 2010 (thousand Barrels per day) ${ }^{1}$ & $381.9(26.9 \%)$ & $838.8(59.1 \%)$ & $38(2.7 \%)$ & $1,418.5$ \\
\hline Total Coal Consumption (Quadrillion Btu, 2010) ${ }^{1}$ & $0.5(0.3 \%)$ & $20.8(13.7 \%)$ & $86.1(56.8 \%)$ & 151.5 \\
\hline Total Petroleum Consumption ( Quadrillion Btu, 2010) ${ }^{1}$ & 5.2 & 36.0 & 25.5 & 175.0 \\
\hline Total Petroleum Consumption (Thousand Barrels Per Day, 2010) ${ }^{1}$ & $2,560(2.9 \%)$ & $19,180.1(22.0 \%)$ & $12,507.9(14.3 \%)$ & 87,213 \\
\hline Total Primary Energy Consumption (Quadrillion Btu, 2009) ${ }^{1}$ & $10.3(2.1 \%)$ & $94.5(19.6 \%)$ & $111.9(23.2 \%)$ & 483.0 \\
\hline $\begin{array}{l}\text { Total Carbon Dioxide Emissions from the Consumption of Energy } \\
\text { (Million Metric Tons, 2010) }^{1}\end{array}$ & $453.9(1.4 \%)$ & $5,610.1(17.7 \%)$ & $10,016.6(31.5 \%)$ & $31,780.4$ \\
\hline
\end{tabular}

1. http://www.eia.gov/forecasts/ieo/index.cfm.

2. http://wardsauto.com/ar/world_vehicle_population_110815.

established the first renewable fuel volume mandate in the United States, this program required 7.5 billion gallons of renewable fuel to be blended into gasoline by 2012 (Environmental Protection Agency. 2005). From the environmental point of view, replacing MTBE and tetraethyl lead with ethanol as octane enhancer, reduced not only groundwater contamination but also harmful tailpipe emissions (e.g. for 2010, the production and use of more than 13 billion gallons of domestic ethanol reduced 21.9 million of tons of $\mathrm{CO}_{2} \mathrm{e}$ ) (Renewable Fuels Association, 2011a).

The RFS was further expanded in 2007 under the Energy Independence and Security Act (EISA) of 2007 to include diesel, in addition to gasoline to increase the volume of renewable fuel required to be blended into transportation fuel from 9 billion gallons in 2008 to 36 billion gallons (bgy) by 2022. This constitutes a four-fold increase over current biofuel production and $25 \%$ of current motor fuel use. The mandate envisions eventual substitution of advanced cellulosic biofuels for currently produced corn based ethanol. But while achieving this goal, it doubles the use of corn based ethanol despite widespread concerns about increased food prices (Huffaker, 2010). A study carried out by the Department of Energy (DOE) and the USDA reported that over 1.3 billion dry tons per year of biomass potential, enough to produce biofuels to meet more than one-third of the current demand for transportation fuels, are available in the US (Perlack, et al. 2005). In Europe, the European Commission also plans to progressively substitute $20 \%$ of the conventional fossil fuels with alternative fuels in the transport sector by 2020 (Hahn- Hägerdal et al., 2006).

Corn used in the alcohol industry has led to record prices of over $\$ 8$ per bushel in 2011, the demand has stimulated the planting of corn crops over the Corn Belt, and it is estimated that close to 90 million acres were planted in 2011 (USDA, 2011). Ethanol production from corn requires substantial amount of water (Mubako and Lant, 2008), part of it is consumed by evaporation from cooling towers and evaporators during distillation. For example, some ethanol plants in the US use from 3.5 to 6 gallons of water per gallon of ethanol produced (Institute for Agriculture and Trade Policy, 2006). Modern ethanol plants employ expensive water treatment technologies allowing unconsumed process water to be recycled within the plant, or discharged to freshwater sources (Huffaker, 2010). Mishra and Yeh (2010) estimated that the water requirement (gal/gal EtOH) to produce ethanol from corn was 2.72 and 4.11 for dry and wet milling respectively. Water demands of biorefineries, while modest compared with the irrigation demands of biofuel crops, could substantially affect local water users.

Few months ago, DOE published the goals for the biomass program for the next quinquennium. DOE encourage the production of biofuels nationwide and supports the EISA goal of 36 bgy of renewable transportation fuels by 2022 (US Department of Energy. 2011). The mission of the program is important to emphasize, "Develop and transform our renewable biomass resources into costcompetitive, high-performance biofuels, bioproducts, and biopower through targeted research, development, demonstration, and deployment supported through public and private partnership" (US Department of Energy. 2011). This program manages a diverse portfolio of technologies; one technology, biochemical conversion, is set forth to reduce the estimated processing cost for converting cellulosic feedstocks to ethanol from $\$ 1.85 /$ gallon in 2011 to $\$ 1.41$ by 2012. In order to achieve this goal, the following two issues are critical: Lowering/stabilizing enzyme costs and the improvement of fermentative organisms and biochemical and conversion routes. The largest expected 
reduction in the cost of sugars will be obtained with biochemical conversion technology development in the areas of pretreatment, enzymes, and fermentation organisms. These steps represent \$1.05/gallon from the total cost and are expected to be reduced to $\$ 0.63 \mathrm{c} /$ gallon by 2012 .

\section{The technology: ethanol fermentation}

Today most of the ethanol manufactured in the World is produced from sugar cane and corn from Brazil and the US, respectively, each country supplying almost equal volumes (Table 1, Figure 1). Current technology is based on sugar cane/corn starch conversion to ethanol utilizing yeast. In The US, corn grain ethanol plants produce from 10 to $15 \%$ ethanol, at rates ranging from 1.5 to $2.5 \mathrm{~g} / \mathrm{L} / \mathrm{h}$ (Haefele and Ross, 2009), reaching up to $20 \%$ ethanol when provided with very high substrate levels. Current ethanol production technology makes 2.7 to 2.8 gallons of fuel ethanol from a $56 \mathrm{lb}$. bushel of corn (Haefele and Ross, 2009). The production capacity of fuel alcohol in the US by 2011 was estimated to be 13.5 billion gallons with more than 204 operating plants in 29 states (Renewable Fuels Association, 2011b).

Ethanol production is carried out through a multistep process in a closed-loop biorefinery. The major process steps for a fermentation plant are as follows:

Pretreatment: Starchy feedstocks are broken down into component parts in preparation for hydrolysis. In a dry milling process, which is predominantly used in firstgeneration corn-based ethanol facilities, the feedstock is ground into flour and combined with water to make a mash. In wet-milling processes, feedstocks are combined with water and broken down into simpler parts using chemical processes, such as acid hydrolysis, fiber expansion, or alkaline wet oxidation.

Hydrolysis: Using enzymes, such as glucoamylase and alpha-amylase, the mash from the pretreatment phase is broken down further into component sugars.

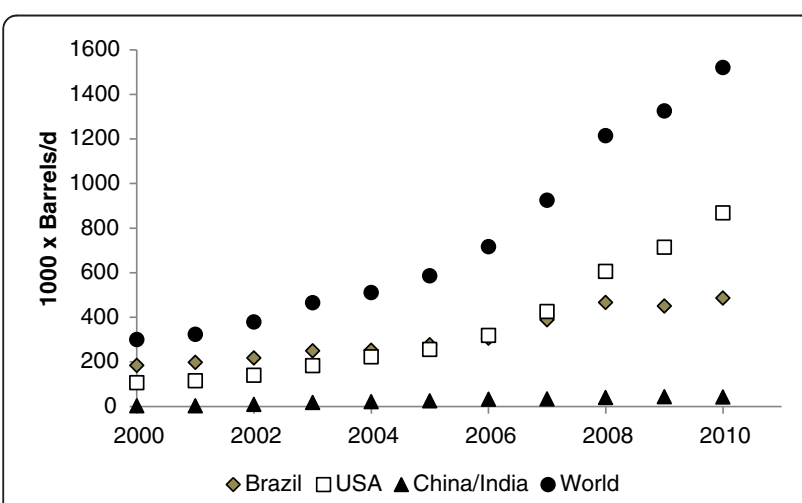

Figure 1 Ethanol production (thousands of barrels per day) in Brazil, US, China/India and in the world from 2000 to 2010.
Fermentation: The slurry from the hydrolysis phase undergoes an anaerobic process in which the sugars are converted into ethanol and carbon dioxide.

Distillation: The brew from the fermentation process is separated and concentrated into 95 percent pure alcohol, water, and other residues. Ethanol must be 95.6 percent by volume to be effective as a mobile fuel.

Dehydration: The resulting alcohol-water mixture is passed through molecular sieves to further absorb water and bring the ethanol mixture to 99.5 percent by volume. At this stage, denaturing agents are added to the ethanol mixture to render it unfit for consumption.

In addition, ethanol could also be produced from lignocellulosic biomass (grasses, agriculture residues, such as cobs, stalks, and leaves, wood wastes, fast growing trees, sugar wastes, citrus and rice wastes, the non-edible parts of plants and municipal wastes) (Lynd et al. 2005). Cellulosic ethanol is a new approach that may alleviate land use and related concerns. The obvious advantage of cellulosic ethanol is its dependence on abundant and diverse raw materials rather than traditional feedstocks, and because humans cannot digest cellulose, it does not compete with food production. Furthermore, exploiting the cellulose in corn plants or sugar cane, rather than the kernels, could double corn's ethanol yield. Pimentel (2001) found that the corn- based ethanol yields net energy losses, but when the byproduct (e.g. DDGS, Distillers Dried Grains with Solubles, a livestock feed) of the distillates are included in the analysis, the ethanol production from corn yields $25 \%$ more energy than invested in its production (Hill et al., 2006).

\section{The problem}

Terrestrial gross primary production ranges from 56 to 120 billion metric tons per year (Beer et al. 2010; Field et al. 1998). In nature, the two dominant simple sugars are D- xylose and D- glucose, 5 and 6 carbon sugars. These two sugars, in combination with other minor sugars, serve as building blocks for the production of more complex carbohydrates, such as lignocellulose, which is the structural component in the stem, trunk and leaves. Lignocellulose is mainly composed of cellulose and hemicellulose and lignin. Generally, lignocellulosic biomass contains 35 - 50\% cellulose, 25 - 30\% hemicelluloses and 20 - 25\% lignin (Mabee et al., 2006; Girio et al. 2010).

Cellulose is the most abundant molecule in nature, it is a $\mathrm{D}$ - glucose polymer but its bond structure is the $\beta-1,4$ linkages. Microbial degradation of cellulosic biomass is performed by mixtures of hydrolytic enzymes collectively known as cellulases. At least three enzymes have to cooperate: endoglucanase, exoglucanase, and $\beta$-glucosidase, which act in a synergistic manner in biomass degrading microbes. Some of the exoglucanases initiate their action 
from the end of cellulose chains and liberate cellobioses along cellulose chains (Murashima et al. 2002).

Some bacteria and fungi are capable of rapid and efficient degradation of cellulose (Lynd et al. 2002). The ability to degrade amorphous cellulose, soluble cellulose analogues, such as carboxymethyl cellulose, and hemicelluloselike substrates is relatively widespread. Cellulotic organisms and cellulases are extremely diverse. There are at least eleven cellulose families based on their similarities based on their amino acid sequence. Cellulase, contrasts from most enzymes because they degrade an insoluble substrate. Almost all enzymes that degrade insoluble substrates contain a substrate binding domain, which is usually joined to the catalytic domain (CBM) (Wilson. 2011).

Cellulases can also be susceptible to interference from various noncellulosic substances. Tejirian and Xu (2010) showed cellulases inhibition by ferrous/ferric ions. Their findings are supported by the fact that all microbial life cycles depend on redox chemistry, and many general microbial processes are of a redox nature. Microbes can be grouped as aerobes (reduces $\mathrm{O}_{2}$ to $\mathrm{H}_{2} \mathrm{O}$ ), nitrate reducers or denitrifiers (reduces $\mathrm{NO}_{3}^{-}$to $\mathrm{N}_{2}$ ), Mn (IV) reducers (reduce $\mathrm{MnO}_{2}$ to $\mathrm{Mn}$ (II)), $\mathrm{Fe}$ (III) reducers (reduces $\mathrm{Fe}_{2} \mathrm{O}_{3}$ or $\mathrm{FeO}(\mathrm{OH})$ to $\mathrm{Fe}(\mathrm{II})$ ), sulfate reducers (reduces $\mathrm{SO}_{2}^{2-}$ or $\mathrm{S}^{-}$to $\mathrm{HS}$ ), or methanogens (reduce $\mathrm{CO}_{2}$ to $\mathrm{CH}_{4}$ ). They also found that strong iron ion chelators and polyethylene glycols could mitigate the inhibition.

Both anaerobic bacteria, as well as anaerobic fungi, are known to produce multienzyme complexes termed cellulosomes; in contrast, aerobic microorganisms produce their cellulase components as single enzymes. It has been suggested that the cellulosome provide anaerobic microorganisms with an advantage to degrade cellulose more efficiently, since cellulosomal cellulases degrade cellulose in a simultaneous manner rather than in a sequential manner (Murashima et al. 2002). Production of cellulosomes by anaerobic microorganisms is thought to be an evolutionary advantage which may counteract the low energy production by fermentation (Koukiekolo et al. 2005). Utilization of cellulosic biomass is more complex than using pure cellulose, because lignocellulose is a complex structure, in which cellulose and hemicellulose are encapsulated in lignin by hydrogen and covalent bonds, which makes the cellulose inaccessible for reaction with hydrolysis agents (Zinoviev et al. 2010). Hemicellulose, the second most abundant carbohydrate in nature and key component of cell wall structure, is made up of a mix of 5 and 6 carbon sugars, with the dominant sugar being $x y-$ lose. In general, from 15 to $35 \%$ of the plant biomass is made up of hemicellulose (Girio et al. 2010), and its conversion into available fermentable sugars is the deciding element for the overall economization for the production of ethanol from lignocellulose (Chandel et al. 2011). Generally speaking none of the pentose sugars present in hemicellulose can be fermented to ethanol by the commercially ethanologenic available microbes (Antoni et al. 2007), as they lack the xylose utilization pathway consisting of xylose reductase and xylitol dehydrogenase. Many efforts have been made to construct such as strain by cloning pentose utilizing genes into ethanologenic microbes (Hahn- Hägerdal et al. 2007).

\section{Cellulosic alcohol technology}

Traditionally, cellulosic ethanol focuses on producing sugars from biomass and fermenting those sugars into fuels. Himmel et al. (2007) summarized the natural factors believed to contribute to the recalcitrance of lignocellulosic feedstock to chemicals or enzymes. Normally, cultivation of cellulosic material with pure culture of cellulosic microorganisms results in a cellulose hydrolysis yield that is lower than $20 \%$ of the theoretical. As result cellulosic process design nearly always include a pretreatment step (Lynd et al. 2002). The lack of industrially suitable microbes for converting biomass into ethanol has been a major technical barrier. The characteristics required for an industrially appropriate ethanolic microorganism were summarized by Dien et al. (2003). Among them, ethanol yields higher than $90 \%$ of the theoretical, ethanol tolerance to higher than $40 \mathrm{~g} / \mathrm{L}$, an ethanol productivity of $1 \mathrm{~g} / \mathrm{L} / \mathrm{h}$. However, no naturally occurring microorganisms can satisfy all of these features. One constraint is because native strains of ethanolproducing microorganisms, such as $S$. cerevisiae, Pichia stipitis, Escherichia coli and Zymomonas mobilis, cannot achieve effective co fermentation of glucose and xylose due to their intrinsic limitations. To solve this problem it is necessary to genetic modification to introduce pathways for xylose fermentation.

Current strategies to produce fuel ethanol from cellulose can be categorized depending on the process configurations, namely; separate hydrolysis and fermentation (SHF), which involves four discrete process steps. Simultaneous saccharification and fermentation (SSF) consolidates hydrolysis and fermentation of cellulose hydrolysis products into one process step, with cellulase production and fermentation of hemicellulose hydrolysis products occurring in two additional separate process steps. Simultaneous saccharification and co fermentation (SSCF) involves two process steps: cellulase production and a second step in which cellulose hydrolysis and fermentation of both cellulose and hemicellulose hydrolysis products occurs (Lee 1997; Lynd et al. 2002).

This technology has several problems; including the growth inhibition by harmful products formed during biomass hydrolysis, resulting in low alcohol concentration. These problems contribute to the high cost of lignocellulosic ethanol by increasing capital expenditure, reducing product yields, and increasing water volumes 
that must be handled as part of relatively dilute product streams. Similar to the traditional fermentation, the major process steps for cellulosic fermentation plant are as follows:

Pretreatment: Among of the chemical treatments used dilute acid at higher temperature has been widely used as it is highly active, inexpensive and easy to execute. In this step, biomass feedstock undergoes a process to break down the hemicellulose fraction of the feedstock into a mixture of soluble five-carbon sugars, such as xylose and arabinose, and soluble six-carbon sugars, such as mannose, galactose, and glucose, it also reduce cellulose crystallinity and increase the porosity of the materials (Mosier et al. 2005). This partial solubilization makes the remaining solid cellulose fraction more accessible for enzyme saccharification later in the process. A small portion of the cellulose is often converted to glucose in this step, as well as a portion of the lignin fraction may also be solubilized. Other chemical and physical methods such as ozonolysis, alkaline hydrolysis, oxidative delignification, solvent extraction, supercritical fluids, autohydrolysis, steam explosion and ammonia fiber expansion (AFEX) are also effective pretreatments (Girio et al. 2010). Pretreatment unavoidably yields fermentation inhibitors such as organic acids, furans, and phenols. In addition, pretreatment conditions must be tailor-made to the specific chemical and structural composition of the variable, sources of lignocellulosic biomass. Several detoxification methods such as neutralization, calcium hydroxide overliming, use of ion exchange resins, activated charcoal, and use of peroxidase or laccase have shown promising results (Chandel et al. 2011). There is not ideal pretreatment, the most appropriated treatment depend on the recalcitrance of the type of material (Girio et al. 2010).

Conditioning: In some process configurations, the pretreated material goes through a hydrolysate conditioning and/or neutralization process which removes undesirable toxic byproducts formed in the pretreatment process and adjusts the $\mathrm{pH}$ of the reactant.

Hydrolysis/Saccharification: The pretreated material with the remaining solid carbohydrate fraction, primarily cellulose and hemicellulose, is saccharified, releasing glucose and pentose sugars. This can be done with enzymes such as cellulases and hemicellulases. Depending on the process design, enzymatic hydrolysis requires from several hours to several days, after which the mixture of sugars and any unreacted cellulose is transferred to the fermented.

Biological Processing: Currently a fermentation step, an inoculum of a fermenting organism is added and fermentation of all sugars to ethanol is carried out while continuing to utilize the enzymes for further glucose production from any remaining solid cellulose. After a few days of fermentation and continued saccharification, nearly all of the sugars are converted to ethanol. The distillation and dehydration steps are similar to the traditional ethanol production describes above. It is important to point out that without the use of the pentose sugars release from the hemicellulose fraction, the ethanol production will not be able to compete with the ethanol from the grain counterpart.

The discovery or engineering of microorganisms with the ability to convert more efficiently the components of lignocellulosic biomass into sugars has a high priority (Yang et al. 2009). This approach, and perhaps the most promising, is consolidated bioprocessing (CBP), in which cellulase production, substrate hydrolysis, and fermentation are accomplished in a single process step by cellulolytic microorganisms (Lynd et al. 2005). Microorganisms required for CBP are not commercially available; although many research labs and companies are extensively searching. One characteristic to further differentiate CBP with traditional methods is that there is an apparent enzymemicrobe- synergy that results in better cellulase production and hence better ethanol yield.

\section{Noisy microorganisms}

Bacteria the oldest organisms on earth first appeared from the Ocean more than 3 billion (Dagan et al. 2010). Eukaryotes appeared about 2 billion years later, first as single heterotrophic cells followed as eukaryotic algae (Dagan et al. 2010). Among the Eukaryotes, fungi play an important role in the mineralization of organic matter in all environments. It is appropriate to note that the domestication of Saccharomyces cerevisiae can be considered a significant event in human history (reviewed by Mortimer, 2000; Johnson and Echavarri- Erasun 2011). Today, yeasts are the major producer of biotechnology products worldwide, exceeding production, in capacity and economic revenues, to any other group of industrial microorganisms. Traditional industrial uses of yeasts include in the fermentations of beers, cider, wines, sake, distilled spirits, bakery products, cheese and sausages. Other established industrial processes that involve yeasts are the production of fuel ethanol, single cell protein, feeds and fodder, industrial enzymes, and small molecular weight metabolites. Yeasts, especially $S$. cerevisiae, are increasingly being used as hosts for expression of protein biocatalysts and multi-enzyme pathways for the synthesis of fine chemicals and small molecular weight compounds of medicinal and nutritional importance. It is also the principal model eukaryotic organism utilized for fundamental research.

Microorganisms also exhibit remarkable social behavior, which amusingly some researchers have proposed are similar to those performed by insects, vertebrates and humans (Diggle et al. 2007). This conduct result in the ability to detect and respond to changes in the environment for their survival, and as a result, a variety of 
mechanisms have developed by which organisms sense their environment and respond to signals that they detect (Zhou et al. 2007). All the above lead to the use of communication, and in microbes it is done by secreting signaling molecules called auto inducers, a process known as quorum sensing (QS) (Lerat and Moran, 2004; Waters and Bassler, 2005; Gera and Srivastava, 2006). Quorum sensing was first designated by Fuqua et al. (1994) to describe the phenomenon whereby the accumulation of signaling molecules allows a single cell to sense the number of bacteria and therefore the population as a whole can make a coordinated response. Zhou et al. (2007) suggested that a common "noisy" signaling molecule could initiative a collective of uncoupled genetic oscillators which will developed an "on- off" gene expression switch that is sensitive to environmental control and yet highly robust to intracellular molecular noise.

In addition, QS is widely recognized as an efficient mechanism to regulate expression of specific genes responsible for the successful establishment of symbiotic, pathogenic, or commensal relationships with eukaryotic hosts, including motility, exopolysaccharide production, biofilm formation, toxin production, mating, virulence and production of metabolites (Gera and Srivastava, 2006; Gonzalez and Keshavan, 2006). This noisy communication may take different forms, such as the acyl -homoserine lactones (AHL) used for Gram-negative bacteria, peptides used in Gram positive bacteria. Another class of molecules includes metabolic byproducts such as acetate or lactate that are typically not considered as cell to cell communication molecules but, can be used effectively for such purposes (Bulter et al. 2004; Gerchman and Weiss, 2004). In this connection, sub lethal allelopathy could also be particularly effective in shaping community structure and function by altering growth and loss rates (Strom, 2008).

The fungal pathogen Candida albicans was the first eukaryotic microorganism shown to exhibit QS (Mohammed et al. 2006). Tyrosol and farnesol are QS molecules produced by $C$. albicans which accelerate and block, respectively, the morphological transition from yeasts to hyphae. It appears; therefore, that morphogenesis in C. albicans is under complex positive and negative control by the actions of tyrosol and farnesol, respectively (Mohammed et al. 2006; Nickerson et al. 2006).

As such, the ability to block or promote these systems provides a powerful tool to solve many problems and enhance productivity in microbes used in industry. For instance, Butanediol fermentation in two Serratia species has been shown to be dependent of quorum sensing (Van Houdt et al. 2006). Iida et al. (2008) demonstrated a relationship between quorum sensing and oxidative fermentation in acetic acid bacteria. They also postulated that manipulation of the quorum-sensing system is expected to be applicable to the industrial production of not only acid production but also various other materials.

In Vibrio cholerae, QS and 3', 5'- cyclic diguanylic acid (c-di-GMP), reciprocally control biofilm formation (Waters et al. 2008). The biofilm is the preferred lifestyle in the microbial world as it enhances growth and survival by improving the availability to nutrients and shelter from predators and antimicrobials, thus providing a substantial survival advantage to aquatic organisms such as Vibrio species (Yildiz and Visick, 2009). Observations have conclusively shown that biofilm bacteria (attached) predominate, numerically and metabolically, in virtually all ecosystems. A number of phenotypic characteristics of Chromobacterium violaceum ATCC 31532, including production of the purple pigment violacein, hydrogen cyanide, antibiotics, exoproteases and chitinolytic enzymes are known to be regulated by the endogenous AHLNhexanoyl-L-homoserine lactone (HHL) (Chernin et al. 1998). DeAngelis et al. (2008) has postulated that the complex process of rhizosphere nitrogen mineralization could also be controlled by QS activity. In addition to their predominant role of QS in nutrient cycling in soil, QS play a similar key role in wastewater treatment systems. Thompson et al. (2006) showed that in general nutrient limitation may stimulate the production of QS and as a result biofilm formation.

\section{Fuel forces}

Microorganisms are usually grouped into those relying solely on harvesting light, or those relying on the assimilation of organic or inorganic compounds to meet their requirements for energy. Likewise, most biogeochemical studies group microorganisms into photo autotrophs like micro algae and cyanobacteria and heterotrophs, like most heterotrophic bacteria. Although this simple classification cannot described the metabolic diversity regarding the role of bacteria in the carbon cycle (Eiler 2006), heterotrophic bacteria predominate the photic zone of Oceans. These bacteria utilize dissolved organic matter excreted mainly by phytoplankton and its dependence is such that there is a close correlation between bacterial and primary production (Azam et al. 1983). Cole et al. (1988) estimated that bacterial production in the water column represented $20 \%$ of planktonic primary production.

In contrast to the photic zone of Oceans, the major source of organic matter in swamps, sea grass meadows and estuaries is detritus derived from vascular plants. The bulk of vascular plant detritus is composed of the structural polymers commonly referred to as lignocellulose. Usually less than $10 \%$ of litter material produced in mangrove forests is consumed alive (Bosire et al. 2005), the remnants become part of the detritus food chain. Wilson (1985) found that $80 \%$ of the decomposition from Spartina alterniflora is largely decomposed in situ, and after 1 year only 10 to $40 \%$ 
of the initial weight of plant litter still remains. Regardless of what initially thought both lignin and lignified plant tissues can also be degraded in the anaerobic sediments (Benner et al. 1984). The degradation of organic matter in mangrove sediments is mediated by both aerobic and anaerobic microbial processes using a variety of electron acceptors (Kristensen et al. 2008).

In this connection degradation of the complex component of plant material such as mangrove tissue required very resourceful microorganism that not only degrade mangrove constituents' compounds, such as carbohydrates, amino acids, lignin derived phenols, fatty acids, triterpenoids and n-alkanes, but also can use or tolerate high concentrations of tannins. Tannins are major constituents of vascular plants, along with lignocellulose, and sometimes comprise more than $20 \%$ of the dry weight of plant materials (Maie et al. 2008). Green leaves of Rhizophora mangle may contain more than $6 \%$ of tannins (Kristensen et al. 2008).

\section{Nutrient cycling}

Diatoms, which are responsible for approximately $20 \%$ of annual primary production and support the most biologically productive regions of the ocean, are known to be chitin producers. The deposition of chitin at diatom girdle bands has the potential to facilitate diatom- microbe interactions, making an attractive source of nutrients for microbes. In this way, chitin functions as an enormous reservoir of organic carbon and nitrogen in the environment (Blokesch and Schoolnik, 2007; Durkin et al. 2009). Chitin, a polymer of $\mathrm{N}$ - acetylglucosamine is the most abundant polymer in the ocean and the second most abundant polymer on earth, surpassed only by cellulose (Durkin et al. 2009). In the aquatic biosphere alone, more than 100 billion metric tons of chitin is produced annually. This huge amount of insoluble material is recycled mainly by chitinolytic bacteria, including members of the genera Vibrio, Aeromonas, Alteromonas, Enterobacter, Pseudomonas, Serratia, Ewingella and Chromobacterium (Chernin et al. 1998; Meibom et al. 2004). Much of the chitin found in oceans is rapidly degraded while in suspension, but some is incorporated into sediments. Anaerobic degradation and utilization of chitin in ocean sediments, similarly to the anaerobic degradation of cellulose in terrestrial environments, is thought to be coupled to processes such as methanogenesis or sulfate reduction via interspecies hydrogen transfer (Reguera and Leschine, 2001). Chitin serves as a nutrient for $V$. cholerae and it induces natural transformation, a process by which it acquires new genes from other microbes in the same habitat (Blokesch and Schoolnik, 2007). The $V$. cholerae link with chitin is an extensively documented phenomenon and best examples of a successful bacteria-substrate interaction (Pruzzo et al.
2008). Chitin utilization is important at the ecosystem level by contributing to both $\mathrm{C}$ and $\mathrm{N}$ recycling. This polymer is one of the most abundant and important sources of nutrients and energy in the marine environment. It is distributed throughout all kingdoms, as it is a crucial component of the cell walls of moulds, yeasts, fungi and certain green algae, and is a major component of the cuticles and exoskeletons of worms, mollusks and arthropods. Attached bacteria metabolize chitin more efficiently than free living bacteria, thus increasing the rate of chitin mineralization in the natural environment.

\section{Cellulose degraders}

Temperature and $\mathrm{pH}$ are major environmental variables that regulate rates of lignocellulose mineralization to $\mathrm{CO}_{2}$, as well as the $\mathrm{C} / \mathrm{N}$ ratio and lignin content (Bridgham and Richardson, 2003). The production of microbial biomass at the expense of lignocellulose is a major pathway of carbon and energy flow in these ecosystems (Benner et al. 1984; Benner and Vaun McArthur, 1988; Mann, 1988). Important metabolic differences between fungi and bacteria suggest that the contributions to plant decomposition in the marine environment by these microorganisms will vary with both physical and chemical aspects of the substrate. High a high $\mathrm{C} / \mathrm{N}$ ratio is believed to stimulate fungi, whereas increasing levels of $\mathrm{N}$ would increase bacterial growth. On the other hand, Pascoal and Cassio (2004), found that leaf decomposition tends to be faster at nutrient polluted sites, with nitrogen and/or phosphorus reported to stimulate both fungal and bacterial activities. Fungi, in particular aquatic hyphomycetes, recognized as dominant players in microbial decomposition of leaf litter in streams, whereas bacteria are thought to increase their importance only after leaf material has been partially broken down. It seems more likely that the natural chemical composition of the substrates, including the solubility and availability of various compounds as well as environmental factors such as temperature, concentration of dissolved nutrients, and $\mathrm{pH}$ contributes more to the explanation (Rousk and Baath, 2007). Decades of marine mycology have clearly demonstrated that marine fungi differ from their terrestrial and freshwater counterparts, both in their taxonomy, morphology and adaptation to the aquatic environment (Jones, 2000). Some of these fungi however, may be present in either aquatic terrestrial habitat. Although, no single factor can account for the observed diversity, again salinity and temperature are the major factors affecting the variety of marine fungi.

Statzell Tallman et al. (2008) found that fungi and fungal like organisms play a major role in the mangrove ecosystems, converting lignin and cellulose and its leachates, into microbial protein. Newell et al. (1987) and Newell and Fell (1997) suggested that oomycotes, are major mycelial decomposers of submerged leaves. The 
oomycotes are mycelial protoctists that have swimming propagules (zoospores) resembling planktonic heterotrophic flagellates. The degradation mechanisms of wood by terrestrial fungi are well known and it is assumed that similar mechanisms exist in marine fungi. Bucher et al. (2004), demonstrates the ability of certain marine ascomycetes to solubilize lignin from wood is equivalent to known terrestrial white- rot basidiomycetes.

Sea grass meadows are, productive ecosystems with an average standing stock sea grass dry weight of $460 \mathrm{~g}$ per $\mathrm{m}^{2}$ (Duarte and Chiscano, 1999). During the past few years, more attention has been given to the role of bacteria in the decomposition of lignin and lignocellulosic plant materials (Kerr et al. 1983). Sea grass roots are colonized by anaerobic bacteria, which not only contribute to the vitality of sea grasses but also to the biogeochemistry of the surrounding sediment (Kusel et al. 1999; Kusel et al. 2001; Nielsen et al. 1999). Kusel et al. (2001) isolated an ethanol producing anaerobic Gram Positive bacterium, from the root of the sea grass Halodule wrightii, which metabolizes certain substrates via the acetyl-CoA pathway, these bacteria could also tolerate and consume limited amounts of $\mathrm{O}_{2}$, which enhance the production of ethanol, lactate, and $\mathrm{H}_{2}$. It was suggested the ability to cope with limited amounts of $\mathrm{O}_{2}$ might contribute to its survival in a habitat subject to daily gradients of $\mathrm{O}_{2}$. In addition, when the transport of $\mathrm{O}_{2}$ to the sea grass roots is not enough to meet the demand for aerobic respiration, then sea grasses, may switch to a fermentation pathway releasing ethanol for short time periods (Smith et al. 1988).

Many microorganisms can attack cellulose, but few taxa can completely degrade it. In terrestrial environments, cellulose tends to be highly lignified and more difficult to degrade; both fungi and Actinomycetes can obtain access to cellulose in woody tissue due to their hyphal growth form. In contrast, little is known about the contributions of different groups of microorganisms to cellulose degradation in aquatic ecosystems. Bacteria appear to be the major degraders of lignocellulose in many aquatic environments (Benner et al. 1986). Gonzalez et al. (1997) found that while both bacteria and fungi can be involved in the degradation of lignin, bacteria are probably responsible for the utilization of the most refractory components. Moran and Hodson (1989) found that Bacteria are capable of using both the soluble fraction of the vascular plant, and the highly refractory lignocellulosic fraction, which is deposited as particulate detritus. They also found that degradation of plant material is predictable as its rate of degradation dependent on nitrogen, lignin content, and the $\mathrm{C} / \mathrm{N}$ ratio. Both sea grasses and mangrove are the major contributors of lignocellulose in coastal marine ecosystems, and although contrary reports fungi play an important role in lignocellulose degradation in these ecosystems (Raghukumar et al. 1999).
In aerobic systems, cellulose is commonly degraded into $\mathrm{H}_{2} \mathrm{O}$ and $\mathrm{CO}_{2}$ while in anaerobic systems both $\mathrm{CH}_{4}$ and $\mathrm{H}_{2}$ are also produced. Cellulolytic species are found within the phyla Thermotogae, Proteobacteria, Actinobacteria, Spirochaetes, Firmicutes, Fibrobacteres and Bacteroids. Of these, approximately $80 \%$ of the isolated cellulolytic bacteria are found within phyla Firmicutes and Actinobacteria. The majority of the gram-positive cellulolytic bacteria is found within Firmicutes and belongs to the class Clostridia and the genus Clostridium (Carere et al. 2008). Among the cellulolytic bacteria, Clostridia have been best studied and characterized. In marine environments, sulfate is plentiful and sulfate reducing bacteria out compete methanogens for $\mathrm{H}_{2} \mathrm{~S}$ (Leschine, 1995).

The microbial degradation of cellulose and hemicellulose is not as well characterized in the oceans as it is in terrestrial systems (Taylor et al. 2006). More than a few marine cellulosic bacterial have been isolated. For instances, Saccharophagus degradans a pleomorphic, gram-negative, aerobic, motile $\gamma$-Proteobacteria isolated from decaying salt marsh. S. degradans can utilize at least 10 distinct complex polysaccharides from diverse algal, plant and invertebrate sources (Suvorov et al. 2011; Taylor et al. 2006).

Several cellulolytic anaerobes have been isolated from the marine environment (Lynd et al. 2002). Clostridium cellulovorans, an anaerobic bacterium, degrades native substrates efficiently (Koukiekolo et al. 2005). Micromonosporas are a group of Actinomycetes that are usually present in large numbers in soil but are also well adapted to seawater (de Menezes et al. 2008; Mincer et al. 2002; Moran and Hodson, 1989). These bacteria are primarily saprophytic and are best known from sediments where they contribute significantly to the turnover of complex biopolymers, such as lignocellulose, hemicellulose, pectin, keratin, and chitin (Mincer et al. 2002). Anaerocellum thermophilum, an anaerobic thermophilic bacterium that grows optimally at $75^{\circ} \mathrm{C}$, efficiently utilizes various types of untreated plant biomass, such as; hardwoods such as poplar, low-lignin grasses Bermuda grasses, and high-lignin grasses such as switch grass as well as crystalline cellulose and xylan (Ranatunga et al. 1997).

Reguera and Leschine (2001), isolated a facultative aerobic bacteria, identified as Cellulomonas uda. This bacteria, could utilized chitin as a source of nitrogen for the degradation of cellulose. It should be taken into account that environments where cellulose accumulates are frequently deficient in nitrogen which may limit plant litter decomposition. In natural environments, the ability to use chitin as a nitrogen source may confer on cellulolytic microorganisms, a selective advantage over other cellulolytic microbes. The genus Cellulomonas comprises facultative aerobic bacteria that have been traditionally characterized by their ability to degrade cellulose. All members of the genus Cellulomonas that were examined 
in this study also degraded chitin, both aerobically and anaerobically, suggesting that the ability to degrade chitin might be widespread among cellulolytic bacteria from terrestrial environments.

\section{Conclusions and recommendations}

The ocean is the mother of life and it is believed that the most primitive forms of life originated from a "primordial soup". It contains a massive variety of marine organisms that are diverse in their physiology and adaptations. Hence, oceans may be considered to be rich in organic compounds favorable for the evolution and growth of life in general. Most of the Earth's microbial diversity is found in the ocean, which ultimately directs an enormous number of bioactive substances (Bhatnagar and Kim, 2010). The oceans contain environments that resemble those that first supported life on earth (Bowler et al. 2009), stress, competition for space and nutrients in the marine environment is a powerful selective force, which has led to endless evolution. Salinity, pressure, temperature and special lighting conditions, contributed to the significant differences between the enzymes generated by marine microorganisms and homologous enzymes from terrestrial microorganisms. Thus constant evolving microbes became the biogeochemical engineers of life on earth (Bowler et al., 2009; Falkowski et al. 2008; Fuhrman, 2009; Zhang and Kim, 2010). There is not organism on earth that could match bacteria importance on number, diversity and its adaptation capability. For instances, the microbiome of the human gut flora comprised of 500 to 1000 bacterial species with two to four million genes and $10^{13}$ bacterial cells, exceeding by 100 and 10 fold the genes of the human genome and the total number of body cells respectively (Sears, 2005). Earth's ocean is estimated to enclose $10^{29}$ bacteria, a number superior than the estimated $10^{21}$ stars in the universe, and its total mass of bacteria exceeds the combined mass of zooplankton and fishes (Pomeroy et al. 2007). In addition, phages which drive the dynamic of marine microbial food web are known to carry and transfer a variety of host genes, as serve as gene reservoirs that change the ecological niche of the reservoir (Rohwer and Vega Thurber, 2009). Production of fuel ethanol from lignocellulosic biomass remains challenging, with many opportunities for improvement. The isolation, characterization and culture of potential microbial strains from the marine environment remain intact. For instances, bacterial communities associated with the woodfeeding molluscs, have been shown to have remarkable cellulosic properties (Zbinden et al. 2010). The gram-negative bacterium Teredinibacter turnerae isolated from the mangrove shipworm Neoteredo reynei is a symbiont that can use cellulose as the sole carbon source and fix dinitrogen under micro-aerobic conditions. T. turnerae is the only known bivalve-gill endosymbiont that can be cultured, and has been shown to present a potential for biotechnological application. (Distel et al. 2002; Trindade-Silva et al. 2009). T.turnerae are also capable of using xylan, pectin, CMC, cellobiose and a wide variety of sugars and organic acids. Interestingly, these shipworms isolates are unique in the capacity of growing in pure cultures, and with cellulose and di nitrogen is a rare combination.

Similar to the relationship chitin-V.cholerae, close associations with cellulose has not been explored. For instances, Cellulose is common in appendicularians and thecate dinoflagellates (Kimura et al. 2001; Kwok and Wong 2003), therefore a relationship or bacteria associated to the degradation of this polysaccharide could exist.

It is clear than tougher microorganisms are needed with higher rates of conversion and yield to allow process simplification through consolidating process steps. Microorganisms from extremes environments such as thermophilic and acidic vents or sea grass sediments where both oxygen fluctuations and ethanol release from the roots provide the correct niche to find the right strains (cellulose degrader, ethanol producing and tolerant strains), the use of blockers or inducers (QS) as a enhancing tool could also result in the isolation of right strains needed by the industry. In addition, phages are known to carry a variety of host genes, not only in a negative effect but as it has been shown it can also augment the metabolism, immunity and distribution of the host in many unexpected ways (Rohwer and Vega Thurber, 2009), it would not be wrong to suggest that the marine environment carry the right soup to obtain the desirable result.

\section{Competing interests}

The author declare that he have no competing interests.

\section{Acknowledgment}

I would like to thank Professor Jack W. Fell from RSMAS, University of Miami, for his advice and correction of the manuscript.

Received: 9 June 2012 Accepted: 30 July 2012

Published: 29 August 2012

\section{References}

Antoni D, Zverlov W, Schwartz WH (2007) Biofuels from microbes. Appl Microbiol Biotechnol 77:23-35

Azam F, Fenchel T, Field JG, Gray JS, Meyer- Reil LA, Thingstad F (1983) The ecological role of water-column microbes in the sea. Mar Ecol Prog Ser 10:257-263

Beer C, Reichstein M, Tomelleri E, Ciais P, Jung M, Carvalhais N, Rödenbeck C, Arain MA, Baldocchi D, Bonan GB, Bondeau A, Cescatti A, Lasslop G, Lindroth A, Lomas M, Luyssaert S, Margolis H, Oleson KW, Roupsard O, Veenendaal E, Viovy N, Williams C, Woodward FI, Papale D (2010) Terrestrial Gross Carbon Dioxide Uptake: Global Distribution and Covariation with Climate. Science 329:834-838

Benner R, Vaun McArthur J (1988) Effects of Temperature on Microbial Utilization of Lignocellulosic Detritus in a Thermally Impacted Stream. Microb Ecol 16:323-330

Benner R, Maccubbin AE, Hodson RE (1984) Preparation, characterization, and microbial degradation of specifically radiolabeled 14C lignocelluloses from marine and fresh water macrophytes. Appl Environ Microbiol 47:381-389 
Benner R, Moran MA, Hodson RE (1986) Biogeochemical cycling of lignocellulosic carbon in marine and freshwater ecosystems: Relative contributions of procaryotes and eucaryotes. Limnol Oceanogr 31:89-100

Bhatnagar I, Kim S-K (2010) Immense Essence of Excellence: Marine Microbial Bioactive Compounds. Mar Drugs 8:2673-2701

Blokesch M, Schoolnik GK (2007) Serogroup Conversion of Vibrio cholerae in Aquatic Reservoirs. PLoS Pathog 3:733-742

Bosire JO, Dahdouh-Guebas F, Kairo JG, Kazungu J, Dehairs F, Koedam N (2005) Litter degradation and $\mathrm{CN}$ dynamics in reforested mangrove plantations at Gazi Bay, Kenya. Biol Conserv 126:287-295

Bowler C, Karl DM, Colwell RR (2009) Microbial oceanography in a sea of opportunity. Nature 459:180-184

Bridgham SD, Richardson CJ (2003) Endogenous versus exogenous nutrient control over decomposition and mineralization in North Carolina peat lands. Biogeochemistry 65:151-178

Bucher WC, Hyde KD, Pointing SB, Reddy CA (2004) Production of wood decay enzymes, mass loss and lignin solubilization in wood by marine ascomycetes and their anamorphs. Fungal Diversity 15:1-14

Bulter T, Lee S-G, Wong WW, Fung E, Connor MR, Liao JC (2004) Design of artificial cell-cell communication using gene and metabolic networks. Proc Natl Acad Sci USA 101:2299-2304

Carere CR, Sparling R, Cicek N, Levin DB (2008) Third Generation Biofuels via Direct Cellulose Fermentation. Int J Mol Sci 9:1342-1360

Chandel AK, Chandrasekhar G, Radhika K, Ravinder R, Ravindra P (2011) Bioconversion of pentose sugars into ethanol: A review and future directions. Biotechnology and Molecular Biology Review 6:8-20

Chernin LS, Winson MK, Thompson JM, Haran S, Bycroft BW, Chet I, Williams P, Gordon P, Stewart SAB (1998) Chitinolytic Activity in Chromobacterium violaceum: Substrate Analysis and Regulation by Quorum Sensing. J Bacteriol 180:4435-4441

Cole JJ, Findlay S, Pace ML (1988) Bacterial production in fresh and saltwater ecosystems: a cross-system overview. Mar Ecol Prog Ser 43:1-10

Dagan T, Roettger M, Bryant D, Martin W (2010) Genome Networks Root the Tree of Life between Prokaryotic Domains. Genome Biol Evol 2:379-392

de Menezes AB, Lockhart RJ, Cox MJ, Allison HE, McCarthy AJ (2008) Cellulose Degradation by Micromonosporas Recovered from Freshwater Lakes and Classification of These Actinomycetes by DNA Gyrase B Gene Sequencing Applied and Environ Microbiol 74:7080-7084

DeAngelis KM, Lindow SE, Firestone MK (2008) Bacterial quorum sensing and nitrogen cycling in rhizosphere soil. FEMS Microbiol Ecol 66:197-207

Dien BS, Cotta MA, Jeffries TW (2003) Bacteria engineered for fuel ethanol production: current status. Appl Microbiol Biotechnol 63:258-266

Diggle SP, Gardner A, West SA, Griffin AS (2007) Evolutionary theory of bacterial quorum sensing: when is a signal not a signal? Phil Trans $R$ Soc B 362:1241-1249

Distel D, Morrill W, MacLaren-Toussaint N, Franks D, Waterbury J (2002) Teredinibacter turnerae gen. nov., sp. nov., a dinitrogen-fixing, cellulolytic, endosymbiotic c-proteobacterium isolated from the gills of wood-boring molluscs (Bivalvia: Teredinidae). Int J Syst Evol Microbiol 52:2261-2269

Duarte CM, Chiscano CL (1999) Sea grass biomass and production: A reassessment. Aquat Bot 65:159-174

Durkin CA, Mock T, Armbrust EV (2009) Chitin in diatoms and its association with the Cell Wall. Eukaryot Cell 8:1038-1050

Eiler A (2006) Evidence for the Ubiquity of Mixotrophic Bacteria in the Upper Ocean: Implications and Consequences. App Environm Microbiol 72:7431-7437

Environmental Protection Agency (2005) Renewable Fuel Standard program., http://www.epa.gov/otaq/fuels/renewablefuels/index.htm

Falkowski PG, Fenchel T, Delong EF (2008) The microbial engines that drive earth's biogeochemical cycles. Science 320:1034-1038

Field CB, Behrenfeld MJ, Randerson JT, Falkowski P (1998) Primary Production of the Biosphere: Integrating Terrestrial and Oceanic Components. Science 281:237-240

Fuhrman JA (2009) Microbial community structure and its functional implications. Nature 459:193-199

Fuqua WC, Winans SC, Greenberg EP (1994) Quorum sensing in bacteria. The LuxR- Luxl family of cell density responsive transcriptional regulators. J Bacteriol 176:269-275

Gera C, Srivastava S (2006) Quorum-sensing: The phenomenon of microbial communication. Curr Science 90:666-677
Gerchman Y, Weiss R (2004) Teaching bacteria a new language. Nat Acad Sci USA 101:2221-2222

Girio FM, Fonseca C, Carvalheiro F, Duarte LC, Marques S, Bogel-Lukasik R (2010) Hemicelluloses for fuel ethanol: A review. Bioresour Technol 101:4755-4800

Gonzalez JE, Keshavan ND (2006) Messing with Bacterial Quorum Sensing. Microbiol Mol Biol Rev 70:859-875

Gonzalez JM, Mayer F, Moran MA, Hodson RE, Whitman WB (1997) Sagittula stellata gen. nov., sp. nov., a Lignin-Transforming Bacterium from a Coastal Environment. Int J Syst Bacteriol 47:773-780

Haefele DM, Ross AJ (2009) Corn: genetics, composition and quality. Chapter 4 : 27-38. In: Ingledew WM, Kelsall DR, Austin GD, Kluhspies C (eds) The Alcohol Textbook. Nottingham University Press, Nottingham, UK

Hahn- Hägerdal B, Galbe M, Gorwa-Grauslund MF, Liden G, Zacchi G (2006) Bio- ethanol- the fuel of tomorrow from the residues of today. Trends Biotechnol 24:549-556

Hahn- Hägerdal B, Karhumaa K, Fonseca C, Spencer-Martins I, Gorwa-Grauslund M (2007) Towards industrial pentose-fermenting yeast strains. Appl Microb Biotech 74:937-953

Hill J, Nelson E, Tilman D, Polasky S, Tiffany D (2006) Environmental, economic and energetic cost and benefits of biodiesel and ethanol biofuels. Proc Natl Acad Sci U S A 103:11206-11210

Himmel ME, Ding SY, Johnson DK, Adney WS, Nimlos MR, Brady JW, Foust TD (2007) Biomass Recalcitrance: Engineering Plants and Enzymes for Biofuels Production. Science 315:805-807

Huffaker R (2010) Water Policy. Protecting water resources in biofuel production 12:129-134

lida A, Ohnishi Y, Horinouchi S (2008) Control of Acetic Acid Fermentation by Quorum Sensing via N-Acylhomoserine Lactones in Gluconacetobacter intermedius. J Bacteriology 190:2546-2555

Institute for Agriculture and Trade Policy (2006) Water Use by Ethanol Plants. IATP, Minneapolis, MN

Johnson EA, Echavarri- Erasun C (2011) Yeast Biotechnology. Vol 1. Chapter 3. In: Kurtzman CP, Fell JW, Boekhout T (eds) The Yeasts, a Taxonomic Study, 5th edn. Elsevier, Amsterdam, the Netherlands, pp 21-44

Jones EBG (2000) Marine fungi: some factors influencing biodiversity. Fungal Diversity 4:53-73

Kerr TJ, Kerr RD, Benner R (1983) Isolation of a Bacterium Capable of Degrading Peanut Hull. Appl Environ Microbiol 46:1201-1206

Kimura S, Ohshima C, Hirose E, Nishikawa J, Itoh T (2001) Cellulose in the house of the appendicularian Oikopleura rufescens. Protoplasma 216:71-74

Koukiekolo R, Cho H-Y, Kosugi A, Inui M, Yukawa H, Doi RH (2005) Degradation of Corn Fiber by Clostridium cellulovorans Cellulases and Hemicellulases and Contribution of Scaffolding Protein CbpA. Appl Environ Microbiol 71:3504-3511

Kristensen E, Bouillon S, Dittmar T, Marchand C (2008) Organic carbon dynamics in mangrove ecosystems: A review. Aquat Bot 89:201-219

Kusel K, Pinkart HC, Drake HL, Devereux R (1999) Acetogenic and sulfate reducing bacteria inhabiting the rhizoplane and deep cortex cells of the sea grass Halodule wrightii. Appl Environ Microbiol 65:5117-5123

Kusel K, Karnholz K, Trinkwalter T, Devereux R, Acker R, Drake HL (2001) Physiological Ecology of Clostridium glycolicum RD-1, an Aerotolerant Acetogen Isolated from Sea Grass Roots. Appl Environ Microbiol 67:4734-4741

Kwok ACM, Wong JTY (2003) Cellulose Synthesis Is Coupled to Cell Cycle Progression at $G_{1}$ in the Dinoflagellate Crypthecodinium cohnii. Plant Physiol 131:1681-1691

Lee J (1997) Biological conversion of lignocellulosic biomass to ethanol. Journal of Biotechnology 56:1-24

Lerat E, Moran NA (2004) The Evolutionary History of Quorum-Sensing Systems in Bacteria. Mol Biol Evol 21:903-913

Leschine SB (1995) Cellulose degradation in Anaerobic Environments. Ann Rev Microbiol 49:399-426

Lynd LR, Weimer PJ, van Zyl WH, Pretorius IS (2002) Microbial cellulose utilization: fundamentals and biotechnology. Microbiol Mol Biol Rev 66:506-577

Lynd LR, van Zyl WH, McBride JH, Laser M (2005) Consolidated bioprocessing of cellulosic biomass: an update. Curr Opin Biotech 16:577-583

Mabee WE, Gregg DJ, Saddler JN (2006) Assessing the emerging biorefinery sector in Canada. Appl Biochem Biotechnol 121:765-778

Maie N, Pisani O, Jaff R (2008) Mangrove tannins in aquatic ecosystems: Their fate and possible influence on dissolved organic carbon and nitrogen cycling. Limnol Oceanogr 53:160-171 
Mann KH (1988) Production and use of detritus in various freshwater, estuarine, and coastal marine ecosystems. Limnol Oceanogr 33:910-930

Meibom KL, Li XB, Nielsen AT, Wu C-Y, Roseman S, Schoolnik GK (2004) The Vibrio cholerae chitin utilization program. PNAS 101:2524-2529

Mincer TJ, Jensen PR, Kauffman CA, Fenical W (2002) Widespread and Persistent Populations of a Major New Marine Actinomycete Taxon in Ocean Sediments. Applied and Environ Microbiol 68:5005-5011

Mishra GS, Yeh S (2010) Analysis of lifecycle water requirements of transportation fuel: Corn based ethanol. Model description. Institute of Transportation Studies, University of California, Research Report UCD-ITS-RR-10-12, Davis

Mohammed AS, Mohammed A, Oteef DY, Flowers TH, Douglas LJ (2006) Production of Tyrosol by Candida albicans Biofilms and Its Role in Quorum Sensing and Biofilm Development. Eukaryot Cell 5:1770-1779

Moran MA, Hodson RE (1989) Bacterial Secondary Production on Vascular Plant Detritus: Relationships to Detritus Composition and Degradation Rate. Applied and Environ Microbiol 55:2178-2189

Mortimer RK (2000) Evolution and variation of the Yeast (Saccharomyces) genome. Genome Res 10:403-409

Mosier N, Wyman C, Dale B, Elander R, Lee YY, Holtzapple M, Ladisch M (2005) Features of promising technologies for pretreatment of lignocellulosic biomass. Bioresour Technol 96:673-686

Mubako S, Lant C (2008) Water Resource requirements of corn based ethanol. Water Resour Res 44:W00A02, 5PP

Murashima K, Kosugi A, Doi RH (2002) Synergistic Effects on Crystalline Cellulose Degradation between Cellulosomal Cellulases from Clostridium cellulovorans. J Bacteriol 184:5088-5095

Newell SY, Fell JW (1997) Competition among mangrove oomycotes, and between oomycotes and other microbes. Aquat Microb Ecol 12:21-28

Newell SY, Miller JD, Fell JW (1987) Rapid and Pervasive Occupation of Fallen Mangrove Leaves by a Marine Zoosporic Fungus. Appl Environ Microbiol 53:2464-2469

Nickerson KW, Atkin AL, Hornby JM (2006) Quorum Sensing in Dimorphic Fungi: Farnesol and Beyond. Appl Environ Microbiol 72:3805-3813

Nielsen JT, Liesack W, Finsterl K (1999) Desulfovibrio zosterae sp. nov., a new sulfate reducer isolated from surface-sterilized roots of the sea grass Zostera marina. Int J Syst Bacteriol 49:859-865

Pascoal C, Cassio F (2004) Contribution of Fungi and Bacteria to Leaf Litter Decomposition in a Polluted River. Appl Environ Microbiol 70:5266-5273

Perlack RD, Wright LL, Turhollow AF, Graham RL, Stokes BJ, Erbach DC (2005) Biomass as a Feedstock for a Bioenergy and Bioproducts Industry: The Technical Feasibility of a Billion-Ton Annual Supply, USDA/DOE, DOE/GO-102005-2135, April 2005., Oak Ridge, TN

Pilgrim C (2009) Status of the worldwide fuel alcohol industry. Chapter 2: 7-17. In: Ingledew WM, Kelsall DR, Austin GD, Kluhspies C (eds) The Alcohol Textbook. Nottingham University Press, Nottingham, UK

Pimentel D (2001) Biomass Utilization, Limits of. In: Encyclopedia of Physical Science and Technology, vol 2, Thirdth edn. Academic Press, San Diego, pp 159-171

Pomeroy LR, Williams PJ, Le B, Azaam F, Hobbie JH (2007) The Microbial Loop. Oceanography 20:28-33

Pruzzo C, Vezzulli L, Colwell RR (2008) Global impact of Vibrio cholerae interactions with chitin. Environm Microbiol 10:1400-1410

Raghukumar C, D'Souza TM, Thorn RG, Reddy CA (1999) Lignin-Modifying Enzymes of Flavodon flavus, a Basidiomycete Isolated from a Coastal Marine Environment. Appl Environ Microbiol 65:2103-2111

Ranatunga TD, Jervis J, Helm RF, McMillan JD, Hatzis C (1997) Identification of inhibitory components toxic toward Zymomonas mobilis CP4(pZB5) xylose fermentation. Appl Biochem Biotechnol 67:185-198

Reguera G, Leschine SB (2001) Chitin degradation by cellulolytic anaerobes and facultative aerobes from soils and sediments. FEMS Microbiol Lett 204:367-374

Renewable Fuels Association (2011a) Ethanol Facts: Environment. http://www.ethanolrfa.org/pages/ethanol-facts-environment

Renewable Fuels Association (2011b) Ethanol Industry Outlook 2011, Building Bridges to a More Sustainable Future. http://www.ethanolrfa.org/page/-/ 2011\%20RFA\%20Ethanol\%20Industry\%200utlook.pdf?nocdn=1

Rohwer F, Vega Thurber R (2009) Viruses manipulate the marine environment. Nature 459:207-212

Rousk J, Baath E (2007) Fungal and bacterial growth in soil with plant materials of different C/N ratios. FEMS Microbiol Ecol 62:258-267
Sears CL (2005) A dynamic partnership: Celebrating our gut flora. Anaerobe 11:247-250

Smith RD, Pregnall AM, Alberte RS (1988) Effects of anaerobiosis on root metabolism of Zostera marina (eelgrass): implications for survival in reducing sediments. Mar Biol 98:131-141

Solomon BD, Barnes JR, Halvorsen KE (2007) Grain and cellulosic ethanol: History, economics and energy policy. Biomass Bioenergy 31:416-425

Statzell Tallman A, Belloch C, Fell JW (2008) Kwoniella mangroviensis gen.nov., sp.nov. (Tremellales, Basidiomycota), a teleomorphic yeast from mangrove habitats in the Florida Everglades and Bahamas. FEMS Yeast Res 8:103-113

Strom SL (2008) Microbial ecology of ocean biogeochemistry: A community perspective. Science 320:1043-1045

Suvorov M, Kumar R, Zhang H, Hutcheson S (2011) Novelties of the cellulolytic system of a marine bacterium applicable to cellulosic sugar production. Biofuels 2:59-70

Taylor LE, Henrissat B, Coutinho PM, Ekborg NA, Hutcheson SW, Weiner RA (2006) Complete cellulase system in the marine bacterium Saccharophagus degradans strain 2-40 T. J Bacteriol 188:3849-3861

Tejirian A, Xu F (2010) Inhibition of Cellulase-Catalyzed Lignocellulosic Hydrolysis by Iron and Oxidative Metal lons and Complexes. Appl Environ Microbiol 76:7673-7682

Thompson LJ, Gray V, Lindsay D, von Holy A (2006) Carbon: nitrogen: phosphorus ratios influence biofilm formation by Enterobacter cloacae and Citrobacter freundii. J App Microbiol 101:1105-1113

Trindade-Silva AE, Machado-Ferreira E, Senra MXV, Vizzoni VF, Yparraguirre LA, Leoncini O, Soares CAG (2009) Physiological traits of the symbiotic bacterium Teredinibacter turnerae isolated from the mangrove shipworm Neoteredo reynei. Genet Mol Biol 32:572-581

U.S. Census Bureau, Statistical Abstract of the United States (2011). http://www.census.gov/compendia/statab/2011/tables/11s1331.pdf

US Department of Energy (2011) Biomass. Multi- Year Program Plan. April 2011. http://www1.eere.energy.gov/biomass/pdfs/mypp_april_2011.pdf

US Energy Information Administration (2011) Energy in Brief: How Dependent Are We on Foreign Oil?. http://tonto.eia.doe.gov/energy_in_brief/ foreign_oil_dependence.cfm

USDA (2011) Acreage. Released June 30, 2011, by the National Agricultural Statistics Service (NASS), Agricultural Statistics Board, United States Department of Agriculture (USDA). http://www.usda.gov/nass/PUBS/ TODAYRPT/acrg0611.pdf

Van Houdt R, Moons P, Hueso Buj M, Michiels CW (2006) N-Acyl-L-Homoserine Lactone Quorum Sensing Controls Butanediol. Fermentation in Serratia plymuthica RVH1 and Serratia marcescens MG. J of Bacteriology 188:4570-4572

Waters CM, Bassler BL (2005) Quorum Sensing: Cell-to-Cell Communication in Bacteria. Annu Rev Cell Dev Biol 21:319-346

Waters CM, Joshua WL, Rabinowitz D, Bassler BL (2008) Quorum Sensing Controls Biofilm Formation in Vibrio cholerae through Modulation of Cyclic Di-GMP Levels and Repression of vpsT. J Bacteriology 190:2527-2536

Wilson JO (1985) Decomposition of 14C Lignocelluloses of Spartina alterniflora and a Comparison with Field Experiments. Appl Environ Microbiol 49:478-484

Wilson DB (2011) Microbial diversity of cellulose hydrolysis. Curr Opin Microbiol $14: 1-5$

World Health Organization (2003) Diet, nutrition and the prevention of chronic diseases: report of a joint WHO/FAO expert consultation, Geneva, 28 January - 1 February 2002. WHO technical report series; 916, Geneva, Switzerland

Yang SJ, Kataeva I, Hamilton-Brehm SD, Engle NL, Tschaplinski TJ, Doeppke C, Davis M, Westpheling J, Adams MWW (2009) Efficient Degradation of Lignocellulosic Plant Biomass, without Pretreatment, by the Thermophilic Anaerobe "Anaerocellum thermophilum" DSM 6725. App Environ Microbiol 75:4762-4769

Yildiz FH, Visick KL (2009) Vibrio biofilms: so much the same yet so different. Trends Microbiol 17:109-118

Zbinden M, Pailleret M, Ravaux J, Gaudron SM, Hoyoux C, Lambourdiere J, Waren A, Lorion J, Halary S, Duperron S (2010) Bacterial communities associated with the wood-feeding gastropod Pectinodonta sp. Patellogastropoda, Mollusca). FEMS 74:450-463

Zhang C, Kim SK (2010) Research and Application of Marine Microbial Enzymes: Status and Prospects. Mar Drugs 8:1920-1934 
Zhou T, Zhang Y, Xu A, Chen L (2007) Synchronizing Independent Gene Oscillators by Common Noisy Signaling Molecule. In: Zhang XS, Chen L, Wu LY, Wang Y (eds) The First International Symposium on Optimization and Systems Biology (OSB'07) Beijing, China, August 8-10, 2007 Proceedings., Beijing, China, pp 156-209

Zinoviev S, Muller-Langer M, Das P, Bertero N, Fornasiero P, Kaltschmitt M, Centi G, Miertus S (2010) Next- Generation Biofuels: Survey of Emerging Technologies and Sustainability Issues. ChemSusChem 3:1106-1133

doi:10.1186/2191-0855-2-46

Cite this article as: Intriago: Marine Microorganisms: perspectives for getting involved in cellulosic ethanol. AMB Express 2012 2:46.

Submit your manuscript to a SpringerOpen ${ }^{\circ}$ journal and benefit from:

- Convenient online submission

- Rigorous peer review

- Immediate publication on acceptance

- Open access: articles freely available online

- High visibility within the field

- Retaining the copyright to your article

Submit your next manuscript at $>$ springeropen.com 